\title{
Market Chain Analysis of Peanut in Bambasi District; Benishangul Gumuz Region, Western Ethiopia
}

\author{
Amente Negussa Bayata ${ }^{1}$, Tewodros Adane Nega ${ }^{2}$ \\ ${ }^{1}$ Department of Agricultural Economics, Assosa University, Assosa, Ethiopia \\ ${ }^{2}$ Department of Agricultural Economics, Debark University, Gonder, Ethiopia
}

Email address:

amentnug@gmail.com (A. N. Bayata), teddyadane222@gmail.com (T. A. Nega)

\section{To cite this article:}

Amente Negussa Bayata, Tewodros Adane Nega. Market Chain Analysis of Peanut in Bambasi District; Benishangul Gumuz Region, Western Ethiopia. American Journal of Plant Biology. Vol. 5, No. 3, 2020, pp. 50-59. doi: 10.11648/j.ajpb.20200503.14

Received: August 21, 2020; Accepted: September 5, 2020; Published: November 23, 2020

\begin{abstract}
Peanut is one of the important agricultural food crops of the world. It is an important source of edible oil and source of vegetable protein. It is also significant source of cash in developing countries that contribute significantly to food security and alleviate poverty. Peanuts have a strong nutritional profile. They are an excellent source of plant-based protein, fiber, and many key vitamins and minerals. Peanuts come in many forms, including roasted, salted, chocolate-coated, and as peanut butter. Different types have different nutritional profiles and various health benefits. This study was initiated to Market Analysis of Peanut in Bambasi District; Benishangul Gumuz Region, Western Ethiopia. The focus of the study was to analyze the peanut market channel in the study area. Different variables were hypothesized to determine quantity of peanut supply to the market. The data was supplemented by primary and secondary sources. The multiple linear regression models were applied to estimate the effects of explanatory variables on quantity of peanut supplied to the market. The results obtained from this analysis indicate extension services, volume of peanut produced, distance to the market, and average price of peanut were found to be the most important significant variables influencing peanut marketing in the district. Therefore, providing extension services, improving volume of peanut produced, improving transportation facilities to strengthen the vertical and horizontal linkages among the marketing agents are recommended to develop and strengthen information on peanut product marketing in the study area.
\end{abstract}

Keywords: Peanut, Market Chain, Analysis, Multiple Linear Regression Model, Bambasi District

\section{Introduction}

\subsection{Background of the Study}

Agriculture is the mainstay of the Ethiopian economy and contributes $41.4 \%$ of the country's gross domestic product (GDP), $83.9 \%$ of the total exports, and $80 \%$ of all employment in the country. The growth of Ethiopia and food security is driven by agriculture which is the foundation of the country's economy and contributes 15 to 17 percent of the government expenditures. It employs 80 percent of the total population, 43 percent of gross domestic product (GDP), and over 70 percent of export value [1].

Peanut is one of the important agricultural food crops of the world. It is the world's important source of edible oil and source of vegetable protein [2]. It is also significant source of cash in developing countries that contribute significantly to food security and alleviate poverty. Developing countries account for $97 \%$ of the world's peanut area and $94 \%$ of the total production [3].

Peanut is an edible seeds of a legume plant that grow to maturity under the ground. Peanut is produced in areas with $40 \mathrm{~mm}$ or more annual rainfall and there should be at least 20 $\mathrm{mm}$ rainfall in the growing season. The most suitable soils are well-drained loose, friable, sandy loams, rich in calcium and moderate amounts of organic matter [4].

According to [5] FAO, the demand for edible oil increases faster than for the other agricultural products increases. This is result in attractive prices. This renders especial benefits for oilseed growing potential countries. The role of markets in reducing poverty and achieving food security in rural areas has been getting increasing attention from development scholars and institutions. Strong links to markets for poor rural producers are essential in increasing agricultural 
production like oilseeds, generating economic growth and reducing hunger and poverty. Improving market links creates a virtuous circle by boosting productivity, increasing incomes and strengthening food security. Better access by small producers to domestic can reliably sell more products at higher [6].

The lowland areas of Ethiopia have considerable potential for increased oil crop production including Peanut. Peanut is mainly grown in Oromia (East and West Harerghe, Wollega, Kelem Wollega, Ilubabor), Amhara, Benishanul Gumuz (Metekel, Asosa, Kemashi, Mao Komo), Southern (Omo), Gambela (Agnuwak) states and Dire Dawa [7]. According to [8] report on area and production of crops, Peanut was produced on $75,255.73$ hectares of land in the 2015/16 cropping season leading to a total production of well over 115,180 tones. The top three peanut producer regional states in Ethiopia are Oromia $(682,939.31 \mathrm{qt})$, Benishangul Gumuz $(307,097.97 \mathrm{qt})$ and Somale $(55,585 \mathrm{qt})$ [9].

\subsection{Statement of the Problem}

One features of agricultural and food marketing in economies is determined by economic, demographic, social and climatic factors as well as the characteristics of the raw materials and consumer products. The crucial role of market chain oriented agricultural marketing system is apparent from the pivotal role that agricultural growth must play in driving overall economic growth of Ethiopia [10].

Market chain analysis is useful studies because it helps us determine whether the market system through which households sell their surplus products or services, and through which they access basic staples and production inputs is efficient and reliable (i.e. competitive). It helps to construct framework at the point when we wish to understand marketing constraints and opportunities for household either for items sold or items they need to purchase [11].

Lack of capital, competition and low quality of peanut, low or irregular quantity of peanut supply, poor road infrastructure, low profit margin, government restriction or high taxes and lack of transportation are challenging Peanut producers in Ethiopia. Inefficient marketing, improper cleaning and sometimes poor contract discipline led opportunities for oilseed export not fully exploited [12].

Producers in the study area revealed that, the increases of the price of peanut steadily make peanut production profitable nevertheless; producers do not directly deal with buyers about the price because of the interference of middlemen. The establishment of big peanut factories for paste production in Addis Ababa is an opportunity for peanut producers to sell their products at reasonable prices and they may get raining in managing peanut production, post-harvest handling and other supports as planned by Food Processing Factory [13]. These shows without well-organized marketing chain, Producers can not enjoy the opportunity of getting fair price and this will affect the desire to produce more at household level. Adequate information on structure, conduct and performance of peanut market is not well identified in Bambasi. This study was therefore, attempted to fill the gap through market chain to make an intervention in the sectors and to generate reasonable benefit for all the stakeholders involved in production and marketing of the product.

\subsection{Objective of the Study}

\subsubsection{General Objective}

The general objective of this study is to analyze the peanut market channel in Bambasi distinct.

\subsubsection{Specifics Objectives}

1) To identify the existing peanut marketing channel in study area.

2) To analyze factors affecting market supply of peanuts in the study area.

3) To identify S-C-P of peanut marketing in the study area.

\section{Research Methodology}

\subsection{Description of the Study Area}

The study was undertaken in Banbasi District, Benishangul Gumuz Regional State, Ethiopia. The District is located in $663 \mathrm{~km}$ far from Addis Ababa (the capital of Ethiopia), $43 \mathrm{~km}$ from Assosa city (the capital of Benishangul Gumuz Regional state). Bordered by the Mao-Komo special district on south-west, Assosa on the northwest, Oda-buldigilu on northeastern by the Oromia regional state the southeast. The agro-ecology of the district is low land agro climatic zone with plain topography, which is geographically located at $9.75^{\circ} \mathrm{N}$ latitude and $34.73^{\circ} \mathrm{E}$ longitude with altitude ranges of 1460 meter above sea level.

The district receives minimum $0.0 \mathrm{~mm}$ and maximum $330.4 \mathrm{~mm}$ rainfall annually on a bimodal distribution. The area experiences two rainy seasons; min or rain-fall in January to March and more extensive rainfall in April to October with long dry season periods in between the minimum and maximum annual temperature ranges from minimum $9.2^{\circ} \mathrm{C}-20.6^{\circ} \mathrm{C}$ and maximum $26.4^{\circ} \mathrm{C}-34.7^{\circ} \mathrm{C}$ in centigrade for the years of 2017 [14]. The natural forest in Bambasi district can be described as tropical mountain rainforest, which is characterized by bamboo, rubber trees and eucalyptus forest.

The demographic status of the study area indicates as the 2018 national census reported a total population for Bambasi district of 66,906 of whom 33,587 were men and 33,319 were women. From this estimated total population of the district about $73.98 \%$ live in rural set-ups while the remaining $26.01 \%$ were urban dwellers. In the rural $67 \%$ of those own their income source depending on farm and in the urban $22 \%$ of those are depending on non-farm. In both urban and rural dawdler $11 \%$ are depending on their income source on farm and non-farm.

\subsection{Sampling Techniques and Sample Size}

Multi stage sampling techniques were used to collect raw data from sample respondents. At the first stage, ten potential growing peanut kebeles were selected purposively. In the 
second stage, using the population list of peanut grower Producers from the district, the capable peanut producer sample size is determined using probability proportional to size sampling technique. The sampling keeping the proportion to each kebeles will select by using [15] Yamane formula is calculated as:

$$
n=\frac{\mathrm{N}}{1+\mathrm{Ne}^{2}}=\frac{5,000}{1+5,000(0.07)^{2}}=200
$$

Where: $\mathrm{n}$-Sample size, $\mathrm{N}$ - Total peanut grower Producers, e- Level of precision (range in which the true value of the population is estimated to be and it is expressed in percentage points)

\subsection{Method of Data Analysis}

\subsubsection{Descriptive Analysis}

The first and second objective of this study was analyzed by descriptive statistics using mean, standard deviation, chisquare $\left(\mathrm{x}^{2}\right), t$-test, frequency table percentile, and maps.

\subsubsection{Econometric Analysis}

Following green (2003) the multiple linear regression models is specified as

$$
\mathrm{Y}_{i}=\mathrm{F}\left(X_{i}\right)+\mathrm{U}_{\mathrm{i}}
$$

Where $\mathrm{Y}=$ quantity of peanut produced for consumption and market, $X_{i}$ - independentvariables, $\mathrm{U}_{\mathrm{i}}$ : error term.

Econometric model specification of supply function in matrix notation is the following

$$
\mathrm{Y}=\beta \mathrm{X}+\mathrm{U}_{\mathrm{i}}
$$

Where: $y_{i}=$ peanut supplied to the market, $\beta=a$ vector of estimated coefficient of the explanatory variables, $X=a$ vector of explanatory variable, $\mathrm{U}_{\mathrm{i}}=$ disturbance term

Before fitting important variable into the regression models for analysis, multicollinearity problem among continuous variable and associations among discrete variables, which seriously affects the parameter estimates were checked. The two measures that are often suggested to test the existence of multicollinearity are variance of inflation factor (VIF) and contingency coefficients (CC). Thus, VIF was used to check multicollinearity among continuous variables. As a rule of thumb, if the VIF is greater than 10 (which will happen if $\mathrm{R}^{2}$ is greater than 0.90 ), the variable is said to be highly collinear [16]. A measure of multicollinearity associated with the variance inflation factors is computed as:

$$
\operatorname{VIF}(\mathrm{Xi})=\left(1-\mathrm{Ri}^{2}\right)^{-1}
$$

Where, $\mathrm{Ri}^{2}$ is the multiple correlation coefficients between explanatory variable, the larger the value of $\mathrm{Ri}^{2}$ is, the higher the value of VIF $\left(\mathrm{X}_{\mathrm{i}}\right)$ causing higher collinearity in the variable $(\mathrm{Xi})$

Contingency coefficient is used to check multicollinearity or association between discrete variables. The value ranges between 0 and1, with 0 indicating no association between the variable and value close to 1 indicating a high degree of association between variables. A popular measure of multicollinearity associated with the $\mathrm{CC}$ is defined as:

$$
\mathrm{CC}=\sqrt{\frac{x^{2}}{N+X 2}}
$$

Where $\mathrm{CC}=$ is contingency coefficient, $x^{2}=$ is chi-square test and $\mathrm{N}=$ is total sample size.

If the value of $\mathrm{CC}$ is greater than 0.75 , the variables are said to be collinear. Conversely, test for heteroscedasticity undertaken for this study.

\subsection{Types and Source of Data}

Both primary and secondary source of cross-sectional data were used for this particular study. In this aspect the primary source of data was collect through structured questionnaire, interview and observation. The secondary data was collected from published and unpublished documents.

\section{Result Discussion and Analysis}

\subsection{Descriptive Analyses}

\subsubsection{Demographic Characteristic}

In an agrarian society, household members are the major source of labor for agricultural activities. The household characteristics differ from one household to the others. For this study out of the 200 sample respondents, $85 \%$ were males and the rest $15 \%$ were female's household head. The study revealed that, female become the head of the household when she is divorced, her husband has health problem which prevent him to be the head of the family, or if she lost. With regard to marital status from the total sample respondents $90 \%, 3 \%$ and $9 \%$ were married, divorced and widow respectively her husband.

About $48 \%$ of the sample respondents were illiterate, $27 \%$ can read and write through informal schooling like religious school and $25 \%$ of the sample respondents were those who attended formal schooling. The average age of sample respondent was 37 years with a standard deviation of 11.4 (Table 1).

Table 1. Description of demographic characteristics for peanut producer.

\begin{tabular}{llll}
\hline Variables & N=200 & Frequency & Percent \\
\hline \multirow{2}{*}{ Sex } & Male & 170 & 85 \\
& Female & 30 & 15 \\
\multirow{3}{*}{ Education } & Illiterate & 96 & 48 \\
& Read \&write & 54 & 27 \\
& Formal education & 50 & 25 \\
Marital status & Married & 180 & 90 \\
& Divorced & 6 & 3 \\
& Widows & 14 & 7 \\
\hline
\end{tabular}

Source: Survey result, 2018.

The majority (36\%) of the respondents had about 9-15 years of peanut production experience. The average years of experience for the entire sample households was about 15 
years, the minimum and maximum years of experience was 2 and 40 years, respectively. This may show that peanut production started in the area about many years ago (Table 2).

Table 2. Distribution of respondent by peanut production experience.

\begin{tabular}{llll}
\hline & & Frequency & Percent \\
\hline & 2-8 years & 50 & 25 \\
Peanut & 9-15 years & 72 & 36 \\
experience & 16-25 years & 46 & 23 \\
& 25-40 years & 32 & 16 \\
Mean & & & 31 \\
\hline
\end{tabular}

Source: Survey result, 2018.

The survey result indicates that, about $50 \%$ and $23.3 \%$ of the sample traders were within the level of primary and secondary school education, respectively, and only $10 \%$ of the traders have some kind of degree certificate. The result also indicates that peanut traders had 4.40 years of experience on the average with standard deviation of 1.52 (Table 3 ).

Table 3. Demographic characteristics of sample trader.

\begin{tabular}{llll}
\hline Variable & Values & Frequency & Percent \\
\hline \multirow{2}{*}{ Sex } & Male & 133 & 66.7 \\
& Female & 67 & 33.3 \\
& Primary & 100 & 50 \\
Education & Secondary & 47 & 23.3 \\
& High school & 33 & 16.7 \\
& Degree & 20 & 10.0 \\
& Single & 47 & 23.3 \\
Marital status & Widow & 13 & 6.7 \\
& Married & 107 & 53.3 \\
& Divorced & 10 & 16.7 \\
\hline
\end{tabular}

Source: Survey result, 2018.

Table 5. Distance to development center and nearby market.

\begin{tabular}{|c|c|c|c|c|c|}
\hline Variable & $\mathbf{N}$ & Min & Max & Mean & SD \\
\hline Market distance & 100 & 15 & 25 & 19.96 & 4.57 \\
\hline Extension office distance & 100 & 1 & 6 & 3.19 & 2.12 \\
\hline
\end{tabular}

Source: Survey result, 2018.

Credit Service: About $83 \%$ of the sample respondents do not take credit and described that they don't want to take loan from the institution due to its inappropriate terms of credit which did not recognize there is kin agriculture and lack of new work plan by producers to effectively utilize the credit taken.

Table 6. Credit taken for peanut production.

\begin{tabular}{llll}
\hline Variable & Response & Sample (n) & Percent \\
\hline \multirow{2}{*}{ Credit taken } & Yes & 34 & 17 \\
& No & 166 & 83 \\
Total & & 200 & 100 \\
\hline
\end{tabular}

Source: Survey result, 2018

Market information and Extension service

The distribution of market information refers to the

\subsubsection{Socio-economic Characteristics}

Input Utilization: Peanut producing Producers are using traditional varieties of seeds retained from their own previous production and/or by purchasing it from other Producers with in there, or/and in their surrounding kebeles. The study affirmed that all sample respondents in the District use of local seed. There are two types of local seeds (locally known as sartu and oldele). From the two, Producers prefer sartu than oldele in terms of its demand in market and its simple uprooting nature.

About $22 \%$ of sample respondents don't apply any chemical fertilizers in the production and they assumed as applying chemical fertilizer is not recommended since ground nut fixes nitrogen by itself. However, $78 \%$ of the sample respondent uses chemical fertilizer due to very poor fertility of their land (Table 4).

Table 4. Fertilizer used for peanut production.

\begin{tabular}{llll}
\hline Variable & Response & Frequency & Percent \\
\hline Fertilizer used for & Yes & 159 & 78 \\
peanut & No & 44 & 22 \\
Total & & 200 & 100 \\
\hline
\end{tabular}

Source: Survey result 2018.

Location: In the study area, peanut producing Producers travel a maximum of $26 \mathrm{kmsand}$ a minimum of $15 \mathrm{kms}$ to reach the nearest market center (Bambasi market; three times a week) with average distance of $19.96 \mathrm{kms}$. The mean distance required to travel to the extension office was about 3.19Kmswith standard deviation of 2.1269 (Table 5). availability of relevant market information to farmers, about demand, supply and price of the crops. The survey result indicates that all respondents not having any market price information access to faraway market places. About $62 \%$ of the producers had nearby market price information before they sale their produce, the rest 38\% do not have any access to price information. Among those who have price information some of them obtained information from trader, and the other from other producers; or through telecommunication services.

From the survey result, about $56.6 \%$ of the producers had nearby market price information through traders, the rest from other producers $(27 \%)$ and traders (16.4). Most of the marketing agents in the study area obtain their information from telecommunication services. 
Table 7. Source information on price, supply and demand.

\begin{tabular}{llllll}
\hline \multirow{2}{*}{ Var. information } & \multicolumn{2}{l}{ Price information } & \multicolumn{2}{l}{ Source of information } \\
\cline { 2 - 5 } & Yes & No & producers & traders & telecommunications \\
\hline Producers & 62 & 38 & 27 & 16.4 & 56.6 \\
Vendors & 46 & 54 & 31 & 18.1 & 50.9 \\
Wholesalers & 70 & 30 & 11 & 14.2 & 74.8 \\
Retailers & 3 & 97 & 15 & 2 & 85 \\
\hline
\end{tabular}

Source: Survey result, 2018.

Information source of supply, about $11 \%$ of the sampled households obtained peanut from other farmer and $27 \%$ of peanut farmer revealed that trader and other farmer being their major source of information about the demand of peanut. The above table indicated inadequate and unorganized flow of information about peanut market to the farmer.

Extension service: The average number of contacts Producers have with extension officers is about two times per month. The study shows that $30 \%$ of respondents had a monthly contact with extension agents, 3\% had contact weekly, $4 \%$ of farmer respondents can contact an extension agent any time they want, $20 \%$ had contact twice in a month and $43 \%$ of them have no contact at all. About $44.5 \%$ of the sampled respondents get advice on cultivation practice, $40.6 \%$ of sample farmer received information about crop choice, fertilizer and chemical application.

\subsection{Peanut Market Participants, Their Roles and Linkages}

Peanut of the study are a pass-through different channel. The channels are generally vertical chain of enterprises that transforms peanut into different products and delivers them to consumers as finished goods or intermediate goods for end buyers. In this study, different stakeholders were involved in bringing peanut from the point of production (farm gate) to the final destination (consumers). According to the data obtained, peanut marketing participants in the study area includes producers/ Producers, village Vendors/assemblers, urban assembler, brokers, wholesalers, retailers, Vendors, processors and final consumers of the product.

Table 8. The percentage of peanut market agent.

\begin{tabular}{lll}
\hline Agents & Frequency & Percent \\
\hline Wholesaler & 15 & 50 \\
Village Vendors & 10 & 33.3 \\
Retailer & 5 & 16.7 \\
Total & 30 & 100 \\
\hline
\end{tabular}

Source: Survey result, 2018.

Producers/Producers: These are the starting point for the chain and act as marketing agents who participate both in production as well as marketing of surplus commodities they produce. At the same time, they transport peanut to the nearest markets by themselves, either using back animals, or animal driven carts, or else medium-size bajaj, over an average distance of $19.6 \mathrm{kms}$. They had several options to sell their product, selling directly or selling through broker to village Vendors/assemblers, urban Vendors, brokers, whole sellers or retailers. As the finding of the study revealed, most
Producers sell peanut straight from the field to who leasers and brokers at Bambasi town. But sometimes Producers sell peanut at the farm gate to other better off Producers to meet their immediate financial need of holly days and other basic needs. They sell at the farm gate at a time of shortage of supply and/or at a time when they are in a problem of cash.

Village assemblers: village assemblers are Producers or part time traders who collect peanut from Producers at farm gate for the purpose of reselling to wholesalers, retailer and consumers. There are few village Vendors who compete with wholesalers. When it is imposable to them to meet quantities of their demand, they employ brokers to collect peanut by paying a commission.

Wholesalers: are those who have sufficient funds to purchase hundreds of quintals of peanut. They are major market participants of the marketing system in the study area who usually buy peanut of larger volume than any other actors in the marketing system. They are seven in number who are licensed to perform who leasing activity in Bambasi District.

Retailers: a person that sells commodity to end users' consumers. They reside in the terminal market and mostly buy peanut from whole sellers and sell to urban consumers. Sometimes they could also directly buy from the producers. Consumers usually purchase the product from retailers as they offer according to the requirement and purchasing power of buyers. Beside buying and selling peanut they often provide processing service by changing shelled peanut to unshelled one.

Vendors: Most Vendors hold roasted peanut. Now a day roasted peanut renders significant livelihood source form any poor throughout the country in general and Bambasi District in particular. They usually purchase between 8 and $16 \mathrm{~kg}$, which they finish selling in 3 to 4 days and most of the time they buy peanut from wholesalers, or assemblers, or other retailers. The cost of roasting peanut is 10 birr for two patra with carrying capacity of around $8.5 \mathrm{kgs}$. Some of the traders in this market sell roasted peanut mixing with salt. In some shops, it is packed for better price but peanut which sold without packing dominates in most markets.

Consumers: They are the last link for peanut market chain. From the consumers' point of view, the shorter the marketing chain, the more likely is there tail price going to be affordable. Consumers for this particular study mean those households who directly bought and consume peanut. They are individual households; bought the commodity for their own consumption only.

Financial capital of sample peanut traders: the average 
initial and current working capital traders during the survey period were estimated to be Birr 2833.33 and Birr25567.80, respectively. Moreover, as it was indicated, the current working capital of peanut traders was about 8.7 times greater than their initial working capital. This shows that peanut business being very attractive business for traders.

Table 9. Financial capital of sample peanut trader.

\begin{tabular}{lllll}
\hline Financial capital (in birr) & N & Minimum & Maximum & Mean \\
\hline Initial financial capital & 30 & 200 & 7000 & Std. Deviation \\
Current financial capital & 30 & 1000 & 125000 & 2289.34 \\
\hline
\end{tabular}

Source: Survey result, 2018.

\subsection{Peanut Market Channel}

Different lines of market channels were identified in the study area. Besides, the percentage of quantity supplied that passed through each channel was compared and based on the result, the channel that went out of District with $31.52 \%$ held the largest, followed by channels that stretched from Farmer $\rightarrow$ Assemblers (rural) $\rightarrow$ Wholesaler $\rightarrow$ Vendors $\rightarrow$ Consumers and Farmer $\rightarrow$ Assembler (rural) $\rightarrow$ Vendors $\rightarrow$ Consumers hosted $16 \%$ and $13 \%$ respectively.

1. Farmer $\rightarrow$ Wholesalers $\rightarrow$ Retailer $\rightarrow$ Vendors $\rightarrow$ Consumers $(10 \%)$

2. Farmer $\rightarrow$ Wholesalers $\rightarrow$ Vendors $\rightarrow$ Consumers $(10 \%)$

3. Farmer $\rightarrow$ Wholesalers $\rightarrow$ Retailer $\rightarrow$ Consumers (10\%)

4. Farmer $\rightarrow$ Assemblers (rural) $\rightarrow$ Wholesalers $\rightarrow$ Retailers $\rightarrow$ Consumers (10\%)

5. Farmer $\rightarrow$ Assemblers (rural) $\rightarrow$ Wholesalers $\rightarrow$ Vendors $\rightarrow$ Consumers (16\%)

6. Farmer $\rightarrow$ Assemblers (rural) $\rightarrow$ Retailers $\rightarrow$ Vendors $\rightarrow$ Consumers $(10 \%)$

7. Farmer $\rightarrow$ Retailers $\rightarrow$ Consumers $(10 \%)$
8. Farmer $\rightarrow$ Retailers $\rightarrow$ Vendors $\rightarrow$ Consumers $(10 \%)$

9. Farmer $\rightarrow$ Assemblers (urban) $\rightarrow$ Vendors $\rightarrow$ Consumers (13\%)

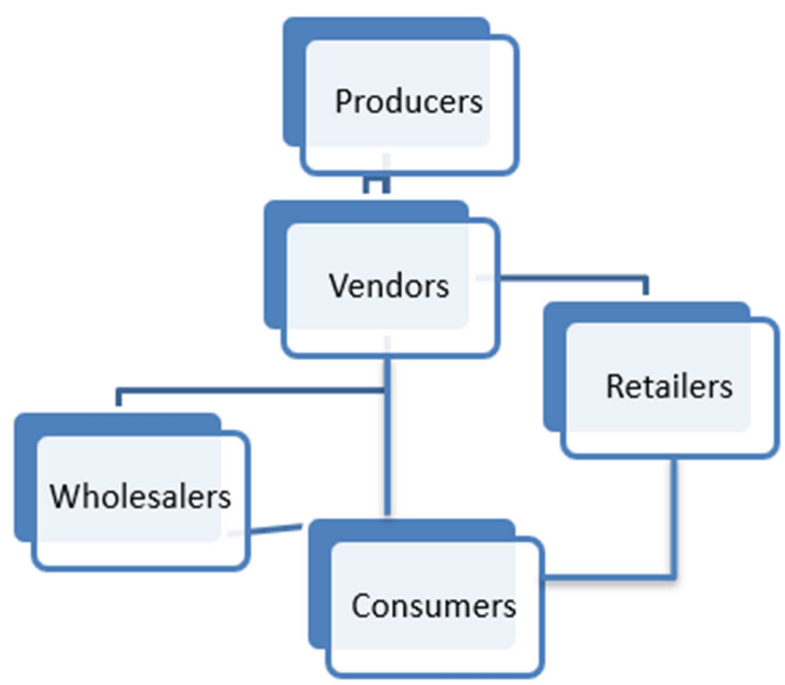

Figure 1. Marketing channel in the study area.

Table 10. Entry barrier in peanut marketing.

\begin{tabular}{lll}
\hline Source of barrier to entry & frequency & percent \\
\hline Lack of capital & 5 & 16.7 \\
Information collusion & 2 & 6.7 \\
Administrative problem & 6 & 20.0 \\
Stiff competition with unlicensed & 4 & 13.3 \\
No barrier & 13 & 43.3 \\
Total & 30 & 100 \\
\hline
\end{tabular}

Source: Survey result, 2018.

\subsection{Structure-Conduct-Performance of the Peanut Market}

\subsubsection{Structure of the Peanut Market}

Barriers to entry into the peanut market: The barriers to entry into the market reflect the competitive relationships between existing traders and potential entrants. If the barriers to entry are low, new traders can easily enter into peanut markets and compete with established traders. However, with the presence of very high barriers to entry, established firms are difficult to stay longer in business.

Among the total trader respondents $43.3 \%$ of them respond that there is no entry barrier to the market where as $56.7 \%$ of them explained that there is entry barrier in peanut marketing specially in whole selling business due to administrative problems, due to shortage of capital, information collusion and stiff competition with unlicensed trader (Table 10).

Administration problems: There is also problem that forced the traders to pay to police officers at road block or check point without any official permission receipts. There is also administrative problem of trade and marketing office of the District in regulating and punishing unlicensed traders and traders with renewed license.

Shortage of capital: The survey result indicated that among various barriers to entry in to the peanut business, shortage of capital being the second. To enter in the market more capital is needed because the traders have to purchase more peanut while Producers regular customers are coming during harvesting (peak purchase) time. Traders should buy 
Producers available amount of peanut that they brought to them, if not they will lose their customer in short period of time.

Stiff competition: Illegal traders were also observed while acting as licensed wholesalers. Since licensed wholesalers spend additional cost for license renewal and income tax then illegal traders are favored relatively than legal trader. These situations weaken the competitive nature of peanut marketing.

\subsubsection{Conduct of Peanut Market}

Market conduct refers to the patterns of behavior that firms follow in adopting or adjusting to the markets in which they sell or buy. It focuses on traders' behavior with respect to various aspects of trading strategies such as buying, selling, transport, storage, information and financial strategy.

Purchasing and pricing strategy: From the survey result $53 \%$ of traders attract their supplier by providing fair weighing. About 30 percent of trader by giving better price and $16 \%$ of peanut trader visit suppliers in order to purchase better quality and quantity of peanut. Most volume of the product was sold at Wednesday and Saturday (Bambasi market) and most traders visit these days to purchase peanut. However, Producers also use Monday and Amusit market (Thursday) at Bambasi to sell their peanut product.

Table 11. Trader's attraction method of suppliers.

\begin{tabular}{lll}
\hline Attractive method & Frequency & Percent \\
\hline Giving better price & 9 & 30 \\
By visiting & 5 & 16 \\
Fair scaling & 16 & 53 \\
Total & 30 & 100 \\
\hline
\end{tabular}

Source: Survey result, 2018.

\subsubsection{Performance of Peanut Market}

Market performance of peanut markets was analyzed by analyzing the marketing margin, by taking into consideration associated marketing costs for key market participants. Hence, on the consideration of $2017 / 18$ production year, costs and purchase prices of the main channel actors, margin at Producers, village assemblers, and Vendors and retailers level was conducted.

\section{Cost and Profitability analysis of peanut traders}

Analysis of cost and profitability of the different traders of peanut namely rural assemblers, roadside trader, wholesaler, retailers were analyzed across the markets. During analysis of cost and profitability, the average purchased price of a quintal of the peanut and the different average transaction costs associated with the marketing process of a single quintal until it reached the next actor was assessed.

Based on the result, average transaction costs incurred across different peanut actors varies. Accordingly, the total costs incurred by village assemblers, wholesalers, retailers, and roadside traders of peanut were birr 9, 95.25, 74.83 and 184.3 respectively. For village Vendors buying and selling of the peanut had taken place on their village market and they were not exposed to different costs associated with marketing process. As a result, village Vendors exercised lowest average transaction costs per quintal than any other traders.

On the other hand, the data indicated that the amount of transaction costs per quintal of peanut incurred by vendors was birr184.3whichwasthehighestcostofalltraders. This could be due to higher costs related to processing raw peanut in to roasted one. Vendors usually purchase between 8 and $16 \mathrm{~kg}$, which they finish selling in 3-4 days. The cost of roasting peanut is 10 birr for two patra with carrying capacity of around $8.5 \mathrm{~kg}$, which is around 117.65 per quintal.

With respect to the profitability of peanut, the overall average profitability indifferent traders indicate that at every stage of transaction, peanut trading business was profitable. Table 11 revealed that roadside traders obtained the highest net profit per quintal that was due to the value addition on peanut that change it from raw peanut to roasted one. Village assemblers obtained least net profit per quintal due to less value addition in the marketing process.

Table 12. Analysis of costs and profitability of peanut for traders.

\begin{tabular}{|c|c|c|c|c|}
\hline Item & V. Assembler & Wholesaler & Retailer & Vendors \\
\hline Purchase price & 1037 & 1400 & 1385 & 1675 \\
\hline Cost of loading -unloading & - & 3 & 5 & 4 \\
\hline Cost of transportation & - & 18 & 20 & 10 \\
\hline Collecting cost & 6 & - & - & - \\
\hline Processing & - & 30 & 30 & 167.65 \\
\hline Income tax & - & 2.50 & 2 & - \\
\hline Total cost/quintal & 1046 & 1463.5 & 1444.33 & 1859.25 \\
\hline Selling price & 1155 & 2350 & 2450 & 2800 \\
\hline Gross profit & 118 & 950 & 1065 & 1125 \\
\hline
\end{tabular}

Source: Own computation, 2019.

Marketing Margins: Marketing margin is a measure of the percentage of price paid by the consumer that is maintained by each agent in the marketing chain. These include the total gross marketing margin, producer's gross marketing margin, and net marketing margin. However, it may also describe price differences between other points in the marketing chain, for example, between producer and wholesale, or wholesale and retail, prices. Therefore, for this section of the study marketing margin was analyzed by considering the average sales prices of different participants in the peanut market 
channel and considering Margin and cost calculation for top five key peanut marketing channels.

Table 13. Market margin for different market agent per qt.

\begin{tabular}{lllll}
\hline Market channel participants & Price (Birr/qt) & Marketing cost & Gross profit (Birr/qt) & Gross marketing margin \\
\hline Producers & 1037 & 23 & 154.03 & 36.87 \\
Village assembler & 1155 & 9 & 118 & 4.21 \\
Vendors & 2800 & 184.3 & 1125 & 12.5 \\
Wholesaler & 2350 & 95.25 & 950 & 42.67 \\
Retailer & 2450 & 74.83 & 1065 & 3.57 \\
\hline
\end{tabular}

Source: Own computation, 2019.

TGMM (complete distribution channel $)=63.13 \%$.

GMMp (Producer participation) $=36.87 \%$.

Results of analysis of marketing costs and margins were used to determine whether there were excess profits and serious inefficiencies or whether wide margins are due to technical constraints (such as transportation bottleneck).

\subsection{Econometric Results}

Factors affecting the choice of peanut market chain

The effects of $\mathrm{X}_{\mathrm{i}}$ on $\mathrm{Y}_{\mathrm{i}}$ were measured by OLS through the multiple linear regression models. Estimated values of the coefficients and results of the multiple linear regression models are presented in table 14.

The effect of significant variables on peanut marketing

Volume of peanut produced: if the volume of peanut increased in the market, demand of the product decreases with proportion to population size. Therefore, the result indicates as volume of peanut increases by 1 unit, then the probability of producers selling at farm gate decreases by $1.6 \%$, ceteris paribus.

Distance from the market: if the distance of household's resident from market increases by 1 unit, then the probability of producers selling at farm gate increases by $3.2 \%$, ceteris paribus. Because producers want to reduce transportation cost and save time. The closer to the market the lesser would be the transportation cost and opportunity time spent. Therefore, the closer market channel to the producers is preferred by the producer.

Average price in 2018/19: shows if the price of peanut increases by 1 unit, the probability of producers selling to local Vendors increases by $4.1 \%$, ceteris paribus. Because of the increase in price, producers prefer to sell their peanut product at farm gate to reduce transportation cost, save time, and gain higher profits.

Market information: implies producer is achieved with due attention to new market information and how market trends influence buying. The result from this study showed, Producers who have more market information sell their peanut commodity earning maximum profit compared to those Producers with insufficient market information.

Table 14. OLS estimation of determinant of peanut market supply.

\begin{tabular}{lllll}
\hline Yi & Coef & Std. err & t & P $>|\boldsymbol{t}|$ \\
\hline Volume & $-0.65^{* * *}$ & 0.20 & -3.32 & 0.013 \\
Age & -0.87 & 0.179 & -4.88 \\
Market distance & $-1.36^{* *}$ & 0.624 & -2.19 & 0.309 \\
Average price & $0.166^{* *}$ & 0.083 & 2.01 & 0.032 \\
Sex & 5.01 & 2.956 & 1.70 & 0.041 \\
Family size & 9.49 & 1.878 & 0.86 & 0.201 \\
Market information & $27.1 *$ & 2.423 & 0.04 & 0.23 \\
Access to credits & 11.84 & 3.04 & 3.89 & 0.071 \\
Education & 11.11 & 2.51 & 4.42 & 0.260 \\
Access to extension & 7.33 & 2.40 & 3.05 & 0.862 \\
-cons & 39.44 & 11.82 & 3.34 \\
\hline
\end{tabular}

$\mathrm{n}=200, \mathrm{R}$-squared $=0.76$, Adj R-Squared $=0.74, * * *, * * *$ indicates level of significance at $10 \%, 5 \%$ and $1 \%$ respectively.

\subsection{Peanut Production and Marketing Constraints}

The most productivity impediments in the area are low yielding varieties, drought, absence of cooperatives, shortage of land, disease, absence of unshelling machine, lack of effective insecticide and herbicide, and shortage of oxen were the main problems of peanut production identified by the respondents in the study area.

Lack of fair weight, lack of marketing information and price fluctuations, lack of direct contact with main market actors, lack of capital, lack of credit services were the main problems of peanut marketing identified by the producers in the study area.

Peanut traders state the following problems as the main constraints against the efficient marketing of peanut. These are corruption, adulteration, competition from illegal traders, and lack of marketing information and capital were the most important problems. The findings of this peanut production and marketing constraints and opportunities are therefore summarized in the table below using the data collected through sample respondent's response, key informant 
interview.

Table 15. Peanut production and marketing constraint and opportunity.

\begin{tabular}{|c|c|}
\hline Opportunities & Constraints \\
\hline $\begin{array}{l}\text { 1. The presence of suitable soil and agro-ecology for peanut } \\
\text { production } \\
\text { 2. Experience of producers in peanut production \& marketing } \\
\text { 3. Willingness of producers to use new peanut production \& } \\
\text { marketing technology } \\
\text { 4. Availability of market demand throughout the year } \\
\text { 5. Presence of established peanut value chain } \\
\text { 6. Willingness of actors to make linkage } \\
\text { 7. Availability of supportive } \\
\text { 8. Government policies and government offices organized to } \\
\text { implement the policies (e.g. District agriculture \&cooperative } \\
\text { promotion offices }\end{array}$ & $\begin{array}{l}\text { 1. Producing of peanut using local seeds } \\
\text { 2. Disease and pest are the major problem of the famers in the study area. } \\
\text { 3. The prevalence of peanut weeds called striga and 'haremedesa' meaning the one } \\
\text { that cause you to loss everything which attack the root of peanut. } \\
\text { 4. Unavailability of coordination among research institutes, relevant government \& } \\
\text { private organizations and producers in seed supply, production \& marketing } \\
\text { functions of peanut } \\
\text { 5. Lack of affordable financial service delivering financial institutions or poor access } \\
\text { to credit services } \\
\text { 6. Absence of cooperatives organized in peanut production \& marketing } \\
\text { 7. Dynamic marketing price and lack of up to date market information for producers } \\
\text { 8. Poor market access roads }\end{array}$ \\
\hline
\end{tabular}

Source: Survey result, 2018.

\section{Conclusions and Recommendations}

\subsection{Conclusions}

Producers of Bambasi district have long last experience and huge potential of peanut producing and the indigenous practices of peanut market chaining. However, Producers still use traditional system of peanut production and informal way of marketing system. Peanut marketing participants were producers/Producers, peanut Vendors, retailers, processors and final consumers of the product. The factors volume of peanut produced, distance from the market, average price and market information affects peanut marketing chain in the study area. Therefore, taking actions that can minimize the identified bottlenecking factors affecting peanut market chain market chain in the study area is necessary.

\subsection{Recommendations}

Based on the findings of the study, the following recommendations are forwarded.

It was found that volume of peanut production in the study area is not sufficient enough for marketing purpose as required. This problem tends to narrow the marketing of peanut producers. Having a confined potential to produce more, there is a chance to increase volume without additional investment only by giving extension service may be through training to the Producers. The Producers should play vital role in increasing volume of peanut product in the study area.

The study revealed that lack of infrastructure thereby distances of the market from Producers influence the peanut market chain of producers. Therefore, government is recommended to improve basic infrastructure for Producers so that they can take their peanut product to the market through available transport services.

Average price of peanut product and lack of market information are identified as factors affecting marketing of peanut products. To solve peanut market chain information problem institutions specially marketing departments are recommended to strengthen the vertical and horizontal linkages among the marketing participants, if it is required to sell peanut product by market price Producers wish.

\section{Acronyms and Abbreviations}

$\begin{array}{ll}\text { FAO } & \text { Food and Agricultural Organization } \\ \mathrm{Kg} & \text { kilograms } \\ \text { qt } & \text { Quintals } \\ \text { S-C-P } & \text { Structure Conduct and Performance }\end{array}$

\section{References}

[1] Addisu Getahun and ErimiasTefera-value chain assessment study of peanut in northwestern Ethiopia, 2017.

[2] Alemayehu et al., 2014. Nutritional Status and Associated Factors among Under-Five Children, Tigray, Northern Ethiopia.

[3] ARD (Agriculture and Rural Development). 2008. Barrier, Catalyst or distraction? Standards, Competitiveness and Africa's Peanut Exports to Europe. LuzB. Diaz Rios and Steven Jaffee. Agriculture and Rural Development Discussion Paper 39, World Bank.

[4] Branson, R. E. and Norvell, D. G. 1983. Introduction to Agricultural Marketing, McGraw- Hill Book Company, New York.

[5] Bucheyeki, T. L., Shenkalwa, M. E., Mapunda, T. and Matata, W. L. (2008). On-farm evaluation of promising peanut varieties for adaptation and adoption in Tanzania. African Journal of Agricultural Research. 3 (8): 531-536.

[6] Bucheyeki, T. L., Shenkalwa, M. E., Mapunda X. T. and MatataW. L. 2010. The Peanut Client Oriented Research inTabora, Tanzania. African Journal of Agricultural Research5 (5): 356-362.

[7] Caliskan Arslan, M. and Arioglu, H. 2008. Effects of sowing date and growth duration on growth and yield of peanut in a Mediterranean-type environment in Turkey. Field Cro. Res. 105 (25): 131-140.

[8] CIAT (Centro International de Agricultural Tropical). 2004. Increasing the Competitiveness of Market Chains for Smallholder Producers. Manual 3: Territorial Approach to Rural Agro- Enterprise Development Project. 
[9] CSA (Central Statistical Agency). 2015. Reports on Area and Production of Crops (Private Peasant Holdings, Meher Season). Addis Ababa, Ethiopia.

[10] FAO, 1977. Diatery fats and oils in human nutrition. Report of a FAO Expert Committee.

[11] Fredu Nega, Mausch. K., Rao K. P. C. and Gizachew Legesse. 2015. Scoping Study on Current Situation and Future Market Outlook of Peanut in Ethiopia. ICRISAT.

[12] Matouse, P., Todob, Y., and Mojoc, O. (2013). Roles of Extension and Ethno-Religious Networks in Acceptance of Resource-Conserving Agriculture among Ethiopian Farmers. International Journal of Agricultural Sustainability. 11 (4): 301-316.
[13] International Fund for Agricultural Development (IFAD, 2017). Report on rural poverty and rural development report.

[14] Nautiyal, 2010. Peanut Post-harvest Operations. Food and Agricultural Organization of the United Nations (FAOSTAT) report, Jakarta, Indonesia.

[15] Wijnands, J., Biersteker, J. and Hiel, R. 2007. Oilseeds Business Opportunities in Ethiopia. Market Study Report on Oil Seed Marketing in Ethiopia Commissioned by Ministry of Agriculture, Nature and Food Quality, the Netherlands. Hague, Netherland.

[16] Yamane (1967) A Simplified Formula: For Proportions size provides a simplified formula to calculate sample sizes. 